International Journal of Social Science and Economic Research

ISSN: 2455-8834

Volume:06, Issue:07 "July 2021"

\title{
A SCOPING REVIEW OF SUICIDE IDEATION IN MALAYSIA AND ITS ECONOMIC COSTS
}

\author{
Norzahirah Mat, Shamzaeffa Samsudin and Shri Dewi Applanaidu \\ Department Of Economics and Agribusiness, School Of Economics, Finance \& Banking, College of \\ Business, Universiti Utara Malaysia
}

DOI: 10.46609/IJSSER.2021.v06i07.016 URL: https://doi.org/10.46609/IJSSER.2021.v06i07.016

\begin{abstract}
This paper is a scoping review on suicide ideation in Malaysia and its economic costs. The published studies were identified using the electronic databases of Elsevier, Pub Med, Proquest, and Google Scholar from 2015 to 2020. An electronic journal such as SAGE Journal was also undertaken. Other journals for example Medical Journal of Malaysia, East Asian Archive of Psychiatry, Malaysia Journal of Psychiatry, Community Mental Health Journal, Asia Pacific Journal of Public Health, and Malaysia Journal of Economics Studies were also included in the current review. A total of 11 studies on suicide ideation in Malaysia that fulfill the inclusion criteria were found and reviewed. Approximately, 63 percent of published studies have emphasized on suicide ideation among adolescents. Off that, the studies emphasized suicide ideation among youth and adults. Mainly, studies related to suicide ideation in Malaysia emphasized adolescents rather than adults or the elderly. Indeed, prior studies only captured the prevalence, factors associated, and implement effective ways to control and prevent suicide ideation. However, the study in Malaysia overlooks the impact of suicide ideation on the economy impacts. Hence, it can be concluded that more specific empirical research on suicide ideation consequences on economics is needed in Malaysia due to the high prevalence of suicide behavior.
\end{abstract}

Keywords: suicide ideation; suicide behavior; economic cost; productivity; risk factors; Malaysia

\section{Introduction}

Suicide has become a serious public health issue all over the world. According to the World Health Organization, (WHO), around eight hundred thousand people die caused by suicide every year, especially among youth. It also reported that around 78 percent of global suicide cases occur in low-middle income countries, and thus will harm the family, communities, and economy. According to Wasserman, the WHO expected around 1.53 million people or closely to 


\section{International Journal of Social Science and Economic Research}

ISSN: $2455-8834$

Volume:06, Issue:07 "July 2021"

3 percent of world deaths would be due to suicide, and approximately 10 to 20 times people would attempt suicide all over the world in the year 2020.

In Malaysia, suicide behavior is indeed a major concern since the prevalence has increased by $60 \%$ over the past 45 years. A previous study stated that Malaysia has a higher prevalence of suicide which is approximately 12 per 100,000 compared to Singapore with 10 per 100,000 and also Thailand with 7.3 per 100,000. Besides, the National Health and Morbidity Survey, (NHMS) reported the prevalence of suicide behavior such as suicide ideation, suicide plan, and suicide attempt for respondents aged 13 and above were $1.7 \%, 0.9 \%$, and $0.5 \%$ respectively. Then, the survey continues to report the prevalence of suicidal behavior among adolescents (aged 16-24) in the year 2012 and 2017. It shows that the prevalence of suicide ideation, suicide attempt, and suicide plan increased through the year observed. Hence, the prevalence of suicide ideation, suicide attempt, and suicide plan in the year 2012 were $7.9 \%, 6.8 \%$, and $6.4 \%$ respectively, and increased to $10 \%, 6.9 \%$, and $7.3 \%$ in the year 2017 .

Suicide, suicide attempt, and suicide ideation are becoming a serious disease burden and also as a significant challenge in most countries. Previous studies have examined the economic impact in terms of productivity loss due to suicide and suicide attempts. Besides, most high-income countries such as Canada, Australia, and the United States are concerned about the issue of productivity loss in terms of direct and indirect costs due to suicide and suicide attempt. For example, in Canada, Clayton and Barcel examined the economic impact of suicide death, and stated the indirect costs due to premature deaths was $\$ 79,353,354.56$ in the year 1996. While in Australia, Kinchin and Doran stated approximately $\$ 2788,245$ of indirect costs in terms of years of life lost and years of productive life years among youth.

In the United States (US), indirect costs in terms of years of productive life lost due to suicide and suicide attempt among those with schizophrenia were $\$ 15.82$ billion. Another study in the US also represents the indirect costs of almost $97.1 \%$ ( $\$ 56.8$ billion) of the overall cost of suicide and suicide attempts. The indirect costs of the study include the net present value of future salaries, fringe benefits, and the value of household productivity lost. Despite the significant problem in suicide behavior (suicide ideation, suicide attempt, \& suicide plan), there is a dearth of information regarding suicide ideation on its economic impact. To the best of knowledge, previous studies only emphasize suicide and suicide attempt and overlook the impact of suicide ideation on the economy. Besides, the number of suicidal ideations is certainly not documented, and suicidal ideation is clearly one of the significant predictors of suicide.

In brief, suicide ideation can be defined as self-thinking about suicide without making plans to commit suicide and it also becomes a significant predictor of future suicidal behavior. According to Harris and Lennings five major factors lead adults in committing suicide namely the past 
attempts of committing suicide, the history of substance abuse, physical health problems, mental problems, and traumatic events. Besides, suicide ideation also becomes an issue that is closely related to mental health disorders as it may lead to the vulnerability of an individual to consider suicide intent. On the rise of the prevalence of suicidal behavior in Malaysia, this study aims to get a picture of suicide ideation and assist decisions makers to understand the magnitude of the adverse outcomes on the economy for future research.

\section{Method}

This paper will conduct a scoping review for examining the published study of suicide ideation in Malaysia and its economic costs. The review will follow the Arksey and O'Malley's scoping review framework which have five following steps including identify the research question, classifying relevant studies, study selection, charting the data, and collating, summarizing and reporting the results.

\subsection{Identifying the research question}

The key research questions are as follows:

i. What is the focus of previous studies on suicide ideation in Malaysia?

ii. What are the economic costs involved in suicide ideation?

iii. What are the direct and indirect cost of suicide ideation in other countries?

The study will apply PCC (population, concept, \& context) framework suggested by the Joanna Briggs Institute for Scoping Reviews. The purpose of the search strategy will be based on inclusion criteria. The PCC framework to direct the research questions is shown in Figure 1.

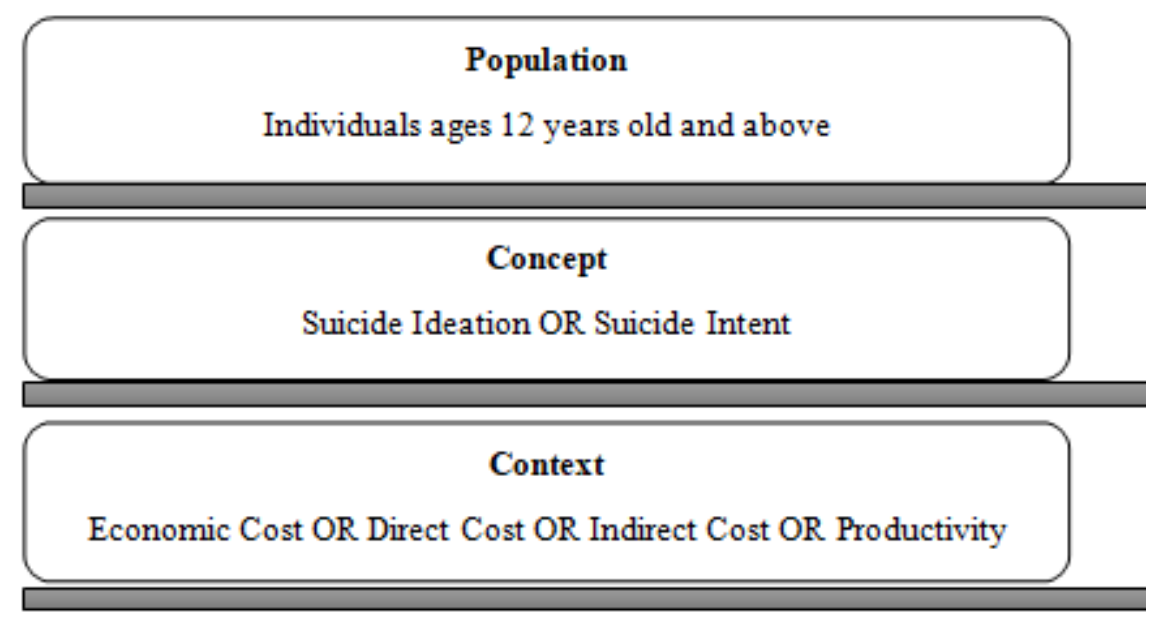

Figure 1: PCC Framework 


\section{International Journal of Social Science and Economic Research}

ISSN: $2455-8834$

Volume:06, Issue:07 "July 2021"

\subsection{Identifying relevant studies}

Studies on suicidal ideation in Malaysia were classified after a thorough search by using electronic databases Elsevier (402-present), Pub Med (611-present), Proquest (601-present), and Google Scholar (5310-present). Besides, electronic journal such as SAGE Journal (229-present) was also undertaken. Other journals such as Medical Journal of Malaysia, East Asian Archive of Psychiatry, Malaysia Journal of Psychiatry, Community Mental Health Journal, Asia Pacific Journal of Public Health, and Malaysia Journal of Economics Studies were also reviewed. The keywords used in the study were "suicide ideation" OR "suicide intent", AND "productivity" OR "economic costs" OR "direct costs" OR "indirect costs" AND "Malaysia". Possibly, these keywords were selected by observing at the frequency in the previous paper collected and it has purposely taken in order to capture as many as published papers.

\subsection{Study selection}

The following keywords addressed in the searching process identified through title, abstract, and full-text screening. Developing the inclusion and exclusion criteria will ensure the clear objective to be achieved for the relevance citation. Hence, the exclusion criteria of the study include the elimination of conceptual paper, published studies before the year of 2015, abstract, conference paper, language other than English, letter to the editor, and studies that are not related to suicidal ideation/intent in Malaysia. While for inclusion criteria, there are three items listed. First, published studies in Malaysia taken from the year 2015 until the year 2020. Second, only empirical studies were included. Third, the study considered those in adolescents age ( $>10$ years old) and above as this study attempt to shed light on the impact of suicide ideation and its economic costs. However, past studies of suicide intent/ideation related to productivity, economic costs, direct costs, or indirect costs in other countries also have been explored as a guide for researchers and policymakers to understand the economic costs due to suicide behavior and shed light for future research.

\subsection{Charting the data}

In brief, the study yields 7153 articles associate with suicide ideation based on all the keywords. After removal for duplicates, they were 6392 articles left. After screening, 31 articles were found suitable and recorded while the other two articles cannot be retrieved. Of that, 29 articles were retrieved and have been assessed for eligibility. As a result, there were 14 articles excluded due to the inclusion criteria, and only 11 articles on suicide ideation in Malaysia deemed acceptable and included in the present study. By using the flow chart from Moher, Liberati, Tetzlaff, and Alman, the literature search has been illustrated as Figure 1.

\subsection{Collating, summarizing and reporting the results}


International Journal of Social Science and Economic Research

ISSN: 2455-8834

Volume:06, Issue:07 "July 2021"

Table 1.1 portrays the following important features of relevant studies on suicide ideation in Malaysia including: i) study number and reference, ii) study population, iii) gender, iv) age, v) marital status, vi) ethnicity, vii) education level, viii) employment status, and ix) outcomes of the study. The information gathered from this study currently important and it could provide some direction for future research. Target groups that are among adolescents aged 12 years old and above as the population give a sense of the economic costs. Besides, ethnicity also includes in the study since Malaysia consists of a multiethnic society. Information on sex also would provide the data on which gender is more likely to have suicide ideation. Marital status, education level, and employment status also included in identifying the associated factor of suicidal ideation. By knowing and understanding the circumstances of suicide ideation in Malaysia, it will be a useful direction for future research in considering the economic costs and also prevent this suicide behavior.

\section{Results}

Eleven studies published from the year 2015 to 2020 that fulfilled the inclusion criteria were selected in the study on the impact of suicide ideation in Malaysia viewing in economic perspectives (Table 1). The sample size in this study is between 114 to 10141 respondents. Approximately, 63 percent of published studies emphasized suicide ideation among adolescents. Off that, published studies emphasized suicide ideation among youth and adults. Among all the published studies, there was only one study focused on females due to the objectives. In terms of marital status, only three studies included the status of respondents while the rest of the studies were not included. On ethnicity, there were three studies focused on Malay, Chinese, and Indian. Another four studies focused on Malay, Chinese, Indian, and others. While the other two studies only make a comparison between Malay and Non-Malay, and another two studies were not available. For education, the majority of the published studies give prominence to those in secondary school, 
International Journal of Social Science and Economic Research

ISSN: 2455-8834

Volume:06, Issue:07 "July 2021"
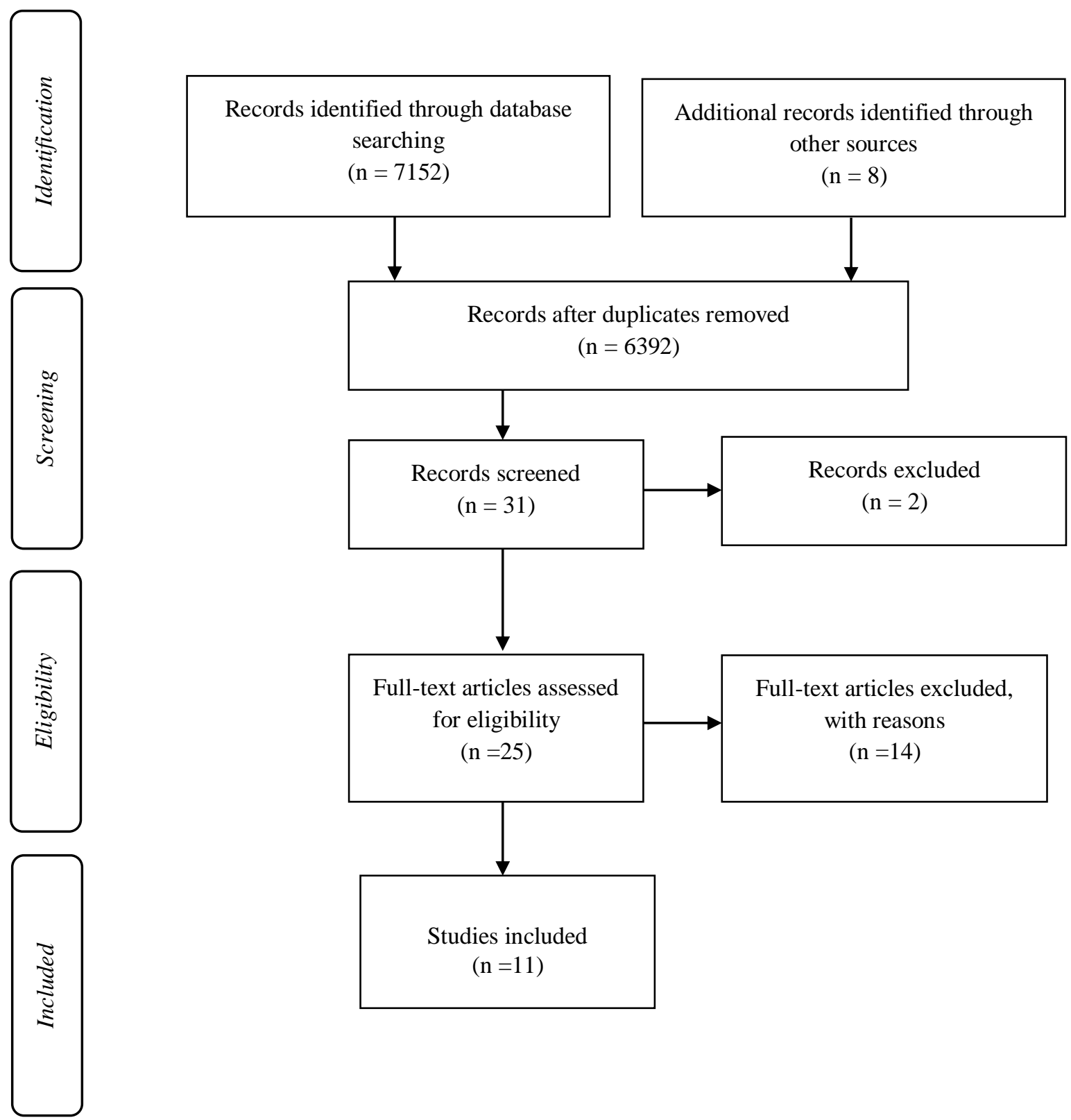

Figure 2: Flow chart of the reviewing process.

and the rest of the study put together those with no formal schooling, primary school, and tertiary that includes diploma and degree. In terms of employment, 9 studies were excluded since they were still in school. While the information on employment status in another two studies was lacking in studies (5) and (6) even though the income has been reported. In Malaysia, most of the previous studies on suicide ideation were among adolescents and youth. Only study (5) examined the factor of suicidal behavior among adults. In fact, prior studies commonly determined the prevalence and factors associated or risk factors of suicide ideation such as in studies (2), (3), 


\section{International Journal of Social Science and Economic Research}

ISSN: $2455-8834$

Volume:06, Issue:07 "July 2021"

(4), (5), and (6). It is because the issue of suicide among adolescents is worrying and has become a public health problem worldwide including Malaysia since the prevalence of suicide among adolescents was increasing. According to the previous studies, suicide ideation among adolescents were higher among female, Indian, single, those who ever had sexual intercourse, those with chronic diseases and mental health problems. These studies addressed loneliness, depression, anxiety, those with no close friends, lack of supportive peers, bully victims, poverty, low-esteem, age, and sex as the risk factors of suicidal ideation. However, several factors such as higher income, household size, education, and physical activity were found not significantly related to suicide ideation. Another study by Ibrahim stated that suicide ideation among youth was higher among males and was associated with age. Whilst for females, the factor associated with suicide ideation were depression and less motivation. Out of 11 studies, three studies explore suicide ideation on how to overcome this problem. For example, religious knowledge could prevent them from thinking about suicide ideation. Besides, family functioning, culture, and social values also continue to play a significant role in preventing suicide ideation. In summary, studies related to suicide ideation in Malaysia mainly focused on adolescents rather than adults and the elderly. Indeed, prior studies only captured the prevalence, factors associated, and recommended ways to control suicide ideation. There is no link established between suicide behaviors such as suicide ideation on its economic costs such as direct and indirect costs in Malaysia.

Whereas in developed countries such as Brazil, Switzerland, and United States, the studies accessed the economic costs of suicide behavior. For instance, Brazil examined the direct and indirect costs among those who attempted suicide compared with the costs of acute coronary syndrome cases. It found the direct costs (\$6168.65) and indirect costs (\$688.08) of suicide attempted per episode are higher than acute coronary syndrome. Another study in Switzerland also examined direct medical costs for medical treatment of suicide attempted per year and it estimated around $\$ 212,110,619$. This study also suggested identifying the indirect costs and the cost-effectiveness of prevention measures. While inthe United States, the study examined the adverse impact of suicide behavior through premature death, disability, medical costs, and productivity loss. The total cost of the suicide behavior was more than $\$ 70$ billion. Of that,92\% of the total costs represented productivity loss and followed by medical care.

\section{Discussion}

From these reviews, it can be concluded that the research on suicide ideation in Malaysia is inadequate especially from economic perspectives. The suicide behavior problem should not be taken lightly since it addressed as a major public health concern. In Malaysia, Aishvarya, Maniam, Sidi, and Oei stated that seven people attempt suicide daily, dominantly among young adults. It also found that Indians presented the highest likelihood of suicide ideation ranging 


\section{International Journal of Social Science and Economic Research}

ISSN: $2455-8834$

Volume:06, Issue:07 "July 2021"

from 18-30 years, 41-50 years, or >51 years. Even though published studies in Malaysia mainly focus on adolescents and higher prevalence were reported, this situation should not be overlooked. Due to previous studies in other countries, the economic costs relating to suicide behavior are high and also involve the indirect cost to family members and also the social environment. For instance, prior studies examined the indirect costs including absenteeism and presenteeism, early retirement, and premature death through the human capital method While the direct costs were the summation of all the costs produced by the illness such as outpatient treatment, cost of hospital care, medications, examinations, medical fee, transportation, and rehabilitation.

Hence, these findings consider as a first step in estimating the economic burden and also productivity caused by suicide behavior in Malaysia. It is because when they become adults and started working, it seemed like they will have the same behavior when they are under pressure. Consequently, it may decrease work productivity and increase national expenditure in terms of direct costs. However, there is a dearth of present research on work and suicide. There were only fewer studies on suicide behavior was conducted particularly among workers in Australia. The study conveyed the emotional burden of workers by presenting the economic cost and help to raise awareness as well as to inform the national call for controlling and preventing actions. A recent study in the United States also stated that the workplace is an additional factor of suicide ideation. It can be concluded that more specific empirical research on suicide behavior in relation to the economic aspect is needed in Malaysia due to the high prevalence of the disorders. In fact, most of the high-income countries such as Canada, Australia, and the United States were truly concerned about this issue and examined the economic costs as it may cause a huge loss of productive capacity and earnings.

\section{Conclusions}

Suicide ideation is an initial point in the suicide pathway. Further studies are essential to examine the economic costs as well as factors associated with suicide ideation. If there is no early prevention program on suicide ideation management and policies, it may create a substantial loss to a country due to suicidal behavior. Besides, high-risk groups of suicide ideation need to be recognized to implement effective interventions. Acquiring a better understanding of the social element of suicide ideation such as social-demographic, social-environmental, and socialpsychological may help to reduce the prevalence and the economic cost of suicide ideation. 
International Journal of Social Science and Economic Research

ISSN: $2455-8834$

Volume:06, Issue:07 "July 2021"

Table 1: Studies on suicide ideation in Malaysia

\begin{tabular}{|c|c|c|c|c|c|c|c|c|}
\hline Study & Population & Gender & Age & $\begin{array}{l}\text { Marital } \\
\text { Status }\end{array}$ & Ethnicity & $\begin{array}{c}\text { Education } \\
\text { Level }\end{array}$ & $\begin{array}{c}\text { Employmen } \\
\text { t Status }\end{array}$ & Outcomes \\
\hline $\begin{array}{l}\text { (1)Chan et al. } \\
\text { (2016) }\end{array}$ & $\begin{array}{l}2789 \quad \text { school } \\
\text { going adolescent }\end{array}$ & $\begin{array}{l}\text { Male } \\
\text { Female }\end{array}$ & 16-17 years & Not included & $\begin{array}{l}\text { Malay } \\
\text { Chinese } \\
\text { Indian }\end{array}$ & $\begin{array}{l}\text { Secondary } \\
\text { school }\end{array}$ & Not included & $\begin{array}{l}\text {-The prevalence of suicide } \\
\text { ideation was } 6.2 \% \text { and } \\
\text { significantly higher among } \\
\text { females and Indian ethnicity. } \\
\text {-The risk factors were } \\
\text { loneliness, anxiety, no close } \\
\text { friends, and lack of } \\
\text { supportive peers. }\end{array}$ \\
\hline $\begin{array}{l}\text { (2) Chan et al. } \\
\text { (2016) }\end{array}$ & $\begin{array}{l}114 \text { single } \\
\text { adolescents } \\
\text { pregnant in } \\
\text { Malaysia }\end{array}$ & Female & $<15$ years & Not included & $\begin{array}{l}\text { Not } \\
\text { available }\end{array}$ & $\begin{array}{l}\text { Secondary } \\
\text { school }\end{array}$ & Not included & $\begin{array}{l}\text {-Sexual behavior and } \\
\text { religious attitude are the main } \\
\text { factor for suicide ideation. }\end{array}$ \\
\hline $\begin{array}{l}\text { (3) Ibrahim et } \\
\text { al. }(2017)\end{array}$ & $\begin{array}{l}1800 \text { students at } \\
\text { Hulu Langat, } \\
\text { Selangor }\end{array}$ & $\begin{array}{l}\text { Male } \\
\text { Female }\end{array}$ & 13-17 years & Not included & $\begin{array}{l}\text { Not } \\
\text { available }\end{array}$ & $\begin{array}{l}\text { Secondary } \\
\text { school }\end{array}$ & Not included & $\begin{array}{l}\text {-The prevalence of suicide } \\
\text { ideation was } 27.9 \% \text {. } \\
\text { The associated factors } \\
\text { addressed were depression, } \\
\text { anxiety, bully victims, and } \\
\text { low-esteem. }\end{array}$ \\
\hline $\begin{array}{lr}\text { (4) } & \text { Ibrahim, } \\
\text { Amit, } & \text { Che } \\
\text { Din, \& } & \text { Ong } \\
(2017) & \end{array}$ & $\begin{array}{l}232 \text { youths from } \\
\text { selected urban } \\
\text { areas in Malaysia }\end{array}$ & $\begin{array}{l}\text { Male } \\
\text { Female }\end{array}$ & $15-25$ years & Not available & $\begin{array}{l}\text { Malays } \\
\text { Non- } \\
\text { Malays }\end{array}$ & $\begin{array}{l}\text {-No } \\
\text { schooling } \\
\text {-Primary } \\
\text { school } \\
\text {-Secondary } \\
\text { school }\end{array}$ & Not included & $\begin{array}{l}\text {-The prevalence of suicide } \\
\text { ideation were higher among } \\
\text { male students rather than } \\
\text { female students. } \\
\text {-The associated factors } \\
\text { correlated were age, } \\
\text { hopelessness, depression, }\end{array}$ \\
\hline
\end{tabular}


International Journal of Social Science and Economic Research

ISSN: $2455-8834$

Volume:06, Issue:07 "July 2021"

\begin{tabular}{|c|c|c|c|c|c|c|c|c|}
\hline & & & & & & $\begin{array}{l}\text {-Tertiary } \\
\text { education }\end{array}$ & & anxiety, and stress. \\
\hline $\begin{array}{l}\text { (5) Cheah, } \\
\text { Azahadi, } \\
\text { Phang, \& Abd } \\
\text { Manaf (2017) }\end{array}$ & $\begin{array}{l}10141 \\
\text { respondents } \\
\text { obtained from } \\
\text { NHMS } 2011\end{array}$ & $\begin{array}{l}\text { Male } \\
\text { Female }\end{array}$ & $>18$ years & $\begin{array}{l}\text { Married } \\
\text { Unmarried }\end{array}$ & $\begin{array}{l}\text { Malay } \\
\text { Chinese } \\
\text { Indian/ } \\
\text { Others }\end{array}$ & $\begin{array}{l}\text { Tertiary } \\
\text { Secondary } \\
\text { Primary }\end{array}$ & $\begin{array}{l}\text { Not } \\
\text { available }\end{array}$ & $\begin{array}{l}\text {-Those with higher income } \\
\text { are less likely to have suicide } \\
\text { ideation. } \\
\text {-Women, single, and those } \\
\text { with chronic diseases are } \\
\text { more likely to have suicide } \\
\text { ideation. }\end{array}$ \\
\hline Study & Population & Gender & Age & $\begin{array}{l}\text { Marital } \\
\text { Status }\end{array}$ & Ethnicity & $\begin{array}{l}\text { Education } \\
\text { Level }\end{array}$ & $\begin{array}{l}\text { Employmen } \\
\text { t Status }\end{array}$ & Outcomes \\
\hline $\begin{array}{l}\text { (6) Cheah, } \\
\text { Azahadi, } \\
\text { Phang, \& } \\
\text { Manaf (2018) }\end{array}$ & $\begin{array}{l}10141 \\
\text { respondents } \\
\text { obtained from } \\
\text { NHMS } 2011\end{array}$ & $\begin{array}{l}\text { Male } \\
\text { Female }\end{array}$ & $>18$ years & $\begin{array}{l}\text { Married } \\
\text { Widowed/ } \\
\text { Divorced } \\
\text { Single }\end{array}$ & $\begin{array}{l}\text { Malay } \\
\text { Chinese } \\
\text { Indian } \\
\text { Others }\end{array}$ & $\begin{array}{l}\text { Tertiary } \\
\text { Secondary } \\
\text { Primary }\end{array}$ & $\begin{array}{l}\text { Not } \\
\text { available }\end{array}$ & $\begin{array}{l}\text {-Suicide ideation is more } \\
\text { likely associated with young } \\
\text { adults, women, Indians and } \\
\text { those with chronic diseases. } \\
\text {-Age, sex, ethnicity, and } \\
\text { health condition were } \\
\text { positively associated with } \\
\text { suicide association. }\end{array}$ \\
\hline $\begin{array}{l}\text { (7) Che Din, } \\
\text { Ibrahim, Amit, } \\
\text { Abdul Kadir, } \\
\text { Abdul Halim } \\
(2018)\end{array}$ & 176 adolescents & $\begin{array}{l}\text { Male } \\
\text { Female }\end{array}$ & 13-19 years & Single & $\begin{array}{l}\text { Malay } \\
\text { Chinese } \\
\text { Indian }\end{array}$ & $\begin{array}{l}\text {-No formal } \\
\text { schooling } \\
\text {-UPSR } \\
\text {-PMR } \\
\text {-SPM }\end{array}$ & Not related & $\begin{array}{l}\text {-The study found that family } \\
\text { alliance and optimistic and } \\
\text { palliative coping strategies } \\
\text { were significant in protecting } \\
\text { adolescents from suicide } \\
\text { ideation. }\end{array}$ \\
\hline
\end{tabular}


International Journal of Social Science and Economic Research

ISSN: $2455-8834$

Volume:06, Issue:07 "July 2021"

\begin{tabular}{|c|c|c|c|c|c|c|c|c|}
\hline & & & & & & $\begin{array}{l}\text {-Certificate } \\
\text {-Diploma } \\
\text {-Degree }\end{array}$ & & \\
\hline $\begin{array}{l}\text { (8) Muhamad } \\
\text { et al. (2018) }\end{array}$ & $\begin{array}{lr}4088 \text { youth from } \\
50 & \text { selected } \\
\text { school } & \end{array}$ & $\begin{array}{l}\text { Male } \\
\text { Female }\end{array}$ & 13-17 years & Not included & $\begin{array}{l}\text { Malay } \\
\text { Chinese } \\
\text { Indian }\end{array}$ & $\begin{array}{l}\text { Secondary } \\
\text { school }\end{array}$ & Not related & $\begin{array}{l}\text {-Sexual abuse and alcohol } \\
\text { abuse were associated with } \\
\text { suicide ideation. } \\
\text {-Female and health risk } \\
\text { behavior among the factors } \\
\text { that associated to suicide } \\
\text { ideation. }\end{array}$ \\
\hline $\begin{array}{l}\text { (9) Ibrahim et } \\
\text { al. (2019) }\end{array}$ & $\begin{array}{l}176 \text { adolescents } \\
\text { in urban areas of } \\
\text { Wilayah } \\
\text { Persekutuan and } \\
\text { Selangor }\end{array}$ & $\begin{array}{l}\text { Male } \\
\text { Female }\end{array}$ & $12-19$ years & Not included & $\begin{array}{l}\text { Malay } \\
\text { Non- } \\
\text { Malay }\end{array}$ & $\begin{array}{l}\text {-Diploma \& } \\
\text { certificate } \\
\text {-SPM } \\
\text {-PMR } \\
\text {-UPSR } \\
\text {-Non } \\
\text { schooling }\end{array}$ & Not related & $\begin{array}{l}\text {-Family support and spiritual } \\
\text { well-being plays a significant } \\
\text { role in suicide ideation. }\end{array}$ \\
\hline $\begin{array}{l}\text { (10) Chin \& } \\
\text { Wu (2020) }\end{array}$ & $\begin{array}{l}852 \text { adolescents } \\
\text { in Kuala Lumpur }\end{array}$ & $\begin{array}{l}\text { Male } \\
\text { Female }\end{array}$ & 13-17 years & Not included & $\begin{array}{l}\text { Malay } \\
\text { Chinese } \\
\text { Indian } \\
\text { Others }\end{array}$ & $\begin{array}{l}\text { Secondary } \\
\text { school }\end{array}$ & Not related & $\begin{array}{l}\text {-Depression is a risk factor of } \\
\text { suicide ideation. } \\
\text {-Self-esteem is a protective } \\
\text { factor. }\end{array}$ \\
\hline $\begin{array}{lr}(11) & \text { Cong, } \\
\text { Ling, } & \& \\
\text { Fitriana } & (2020)\end{array}$ & $\begin{array}{l}852 \text { adolescents } \\
\text { in Kuala Lumpur }\end{array}$ & $\begin{array}{l}\text { Male } \\
\text { Female }\end{array}$ & $13-17$ years & Not included & $\begin{array}{l}\text { Malay } \\
\text { Chinese } \\
\text { Indian }\end{array}$ & $\begin{array}{l}\text { Secondary } \\
\text { school }\end{array}$ & Not related & $\begin{array}{l}\text {-Family functioning and } \\
\text { coping strategy are associated } \\
\text { to suicide ideation. }\end{array}$ \\
\hline
\end{tabular}


International Journal of Social Science and Economic Research

ISSN: 2455-8834

Volume:06, Issue:07 "July 2021"

\begin{tabular}{|l|l|l|l|l|l|l|l|l|}
\hline & & & & & Others & & & \\
\hline
\end{tabular}


International Journal of Social Science and Economic Research

ISSN: 2455-8834

Volume:06, Issue:07 "July 2021"

\section{References}

[1] World Health Organization, "Suicide," 2018. [Online]. Available: http://www.who.int/news-room/fact-sheets/detail/suicide. [Accessed: 27-Jun-2018].

[2] D. Wasserman, Suicide: an Unnecessary Death. London: Martin Dunitz, 2001.

[3] Malaysia Psychiatric Association, "Suicide," 2007. [Online]. Available: http://www.psychiatry-malaysia.org/article.php?aid=504. [Accessed: 18-Jan-2021].

[4] H. Hendin et al., "Suicide and suicide prevention in Asia," World Heal. Organ. Press, pp. $1-108,2008$.

[5] National Health and Morbidity Survey, "Institute for Public Health - NHMS," 2011.

[6] I. Kinchin and C. M. Doran, "The economic cost of suicide and non-fatal suicide behavior in the Australian workforce and the potential impact of a workplace suicide prevention strategy," Int. J. Environ. Res. Public Health, vol. 14, no. 4, Apr. 2017.

[7] S. Czernin et al., "Cost of attempted suicide: A retrospective study of extent and associated factors," Swiss Med. Wkly., vol. 142, no. July, Jul. 2012.

[8] S. M. T. Sgobin, A. L. M. Traballi, N. J. Botega, and R. O. Coelho, "Direct and indirect cost of attempted suicide in a general hospital: cost-of-illness study," Sao Paulo Med J. Sao Paulo Med J, vol. 133, no. 1333, pp. 218-26218, 2015.

[9] D. S. Shepard, D. Gurewich, A. K. Lwin, G. A. Reed, and M. M. Silverman, "Suicide and Suicidal Attempts in the United States: Costs and Policy Implications," Suicide LifeThreatening Behav., vol. 46, no. 3, pp. 352-362, Jun. 2016.

[10] I. Kinchin, C. M. Doran, W. D. Hall, and C. Meurk, "Understanding the true economic impact of self-harming behaviour - Authors' reply," The Lancet Psychiatry, vol. 4, no. 12. p. 901, 2017.

[11] D. Clayton and A. Barcel, "The cost of suicide mortality in New Brunswick, 1996.," Chronic Dis. Can., vol. 20, no. 2, pp. 89-95, 1999.

[12] I. Kinchin and C. Doran, "The Cost of Youth Suicide in Australia," Int. J. Environ. Res. Public Health, vol. 15, no. 4, p. 672, Apr. 2018.

[13] C. S. Palmer, D. A. R. Evicki, M. T. Halpern, and E. J. Hatziandreu, "The Cost of Suicide and Suicide Attempts in the United States.," Clin. Neuropharmacol., vol. 18, pp. S25S33, 1995. 
International Journal of Social Science and Economic Research

ISSN: 2455-8834

Volume:06, Issue:07 "July 2021"

[14] World Health Organization, "Suicide Prevention (SUPRE)," 2012. [Online]. Available: https://www.who.int/teams/mental-health-and-substance-use/suicide-data. [Accessed: 18Jan-2021].

[15] S. Crow, M. E. Eisenberg, M. Story, and D. Neumark-Sztainer, "Are Body Dissatisfaction, Eating Disturbance, and Body Mass Index Predictors of Suicidal Behavior in Adolescents? A Longitudinal Study," J. Consult. Clin. Psychol., vol. 76, no. 5, pp. 887892, Oct. 2008.

[16] T. E. Harris and C. J. Lennings, "Suicide and Adolescence," Int. J. Offender Ther. Comp. Criminol., vol. 37, no. 3, pp. 263-270, Sep. 1993.

[17] A. Abdollahi, M. Abu Talib, S. N. Yaacob, and Z. Ismail, "The Role of Hardiness in Decreasing Stress and Suicidal Ideation in a Sample of Undergraduate Students," $J$. Humanist. Psychol., vol. 55, no. 2, pp. 202-222, Apr. 2015.

[18] H. Arksey and L. O'Malley, "Scoping studies: Towards a methodological framework," Int. J. Soc. Res. Methodol. Theory Pract., vol. 8, no. 1, pp. 19-32, Feb. 2005.

[19] K. Hannes and K. Macaitis, "A move to more systematic and transparent approaches in qualitative evidence synthesis: update on a review of published papers," Qual. Res., vol. 12, no. 4, pp. 402-442, Aug. 2012.

[20] L. Ng et al., "Title and abstract screening and evaluation in systematic reviews (TASER): A pilot randomised controlled trial of title and abstract screening by medical students," Syst. Rev., vol. 3, no. 1, pp. 1-8, Oct. 2014.

[21] D. Moher, A. Liberati, J. Tetzlaff, and D. G. Altman, "Preferred Reporting Items for Systematic Reviews and Meta-Analyses: The PRISMA Statement," PLoS Med., vol. 6, no. 7, p. e1000097, Jul. 2009.

[22] Y. Y. Chan et al., "Prevalence and risk factors associated with suicidal ideation among adolescents in Malaysia," Int. J. Adolesc. Med. Health, vol. 30, no. 3, pp. 1-9, 2016.

[23] N. Ibrahim et al., "Prevalence and predictors of depression and suicidal ideation among adolescents attending government secondary schools in Malaysia," Med. J. Malaysia, vol. 72, pp. 221-227, 2017.

[24] C. W. Cong, W. S. Ling, and M. Fitriana, "Family functioning, coping strategy, and suicidal ideation among adolescents," J. Child Adolesc. Ment. Health, vol. 32, no. 2-3, pp. 131-140, 2020.

[25] N. Che Din, N. Ibrahim, N. Amit, N. B. Abdul Kadir, and M. R. T. Abdul Halim, 
International Journal of Social Science and Economic Research

ISSN: 2455-8834

Volume:06, Issue:07 "July 2021"

"Reasons for living and coping with suicidal ideation among adolescents in Malaysia," Malays J. Med. Sci., vol. 25, no. 5, pp. 140-150, 2018.

[26] S. Czernin et al., "Cost of attempted suicide: A retrospective study of extent and associated factors," Swiss Med. Wkly., vol. 142, no. July, Jul. 2012.

[27] P. S. Corso, J. A. Mercy, T. R. Simon, E. A. Finkelstein, and T. R. Miller, "Medical Costs and Productivity Losses Due to Interpersonal and Self-Directed Violence in the United States," Am. J. Prev. Med., vol. 32, no. 6, 2007.

[28] S. Aishvarya, T. Maniam, H. Sidi, and T. P. S. Oei, "Suicide ideation and intent in Malaysia: A review of the literature," Comprehensive Psychiatry, vol. 55, no. SUPPL. 1. W.B. Saunders, pp. S95-S100, 01-Jan-2014.

[29] M. Cloutier, M. Greene, A. Guerin, M. Touya, and E. Wu, "The economic burden of bipolar I disorder in the United States in 2015," J. Affect. Disord., vol. 226, pp. 45-51, 2018.

[30] L. H. Wee et al., "Anteceding factors predicting absenteeism and presenteeism in urban area in Malaysia," BMC Public Health, vol. 19, no. 4, pp. 1-12, 2019.

[31] K. B. Follmer and D. J. Follmer, "Longitudinal relations between workplace mistreatment and engagement - The role of suicidal ideation among employees with mood disorders," Organ. Behav. Hum. Decis. Process., vol. 162, pp. 206-217, Jan. 2021.

[32] C. M. Doran and R. Ling, "The Economic Cost of Suicide and Suicide Behaviour in the NSW Construction Industryand the Potential Impact of Mates in Construction Suicide Prevention Strategy in Reducing this Cost; Mates in Construction," Brisbane, Australia, 2014.

[33] L. F. Chan et al., "Suicidal ideation among single, pregnant adolescents: The role of sexual and religious knowledge, attitudes and practices," J. Adolesc., vol. 52, pp. 162169, Oct. 2016.

[34] N. Ibrahim, N. Amit, N. Che Din, and H. C. Ong, "Gender differences and psychological factors associated with suicidal ideation among youth in Malaysia," Psychol. Res. Behav. Manag., vol. Volume 10, pp. 129-135, Apr. 2017.

[35] Y. K. Cheah, M. Azahadi, S. N. Phang, and N. H. Abd Manaf, "Sociodemographic, lifestyle and health determinants of suicidal behaviour in Malaysia," Psychiatry Res., vol. 261, pp. 319-324, Mar. 2017.

[36] Y. K. Cheah, M. Azahadi, S. N. Phang, and N. H. A. Manaf, "Association of suicidal 
ideation with demographic, lifestyle and health factors in Malaysians," East Asian Arch. Psychiatry, vol. 28, no. 3, pp. 85-94, 2018.

[37] N. A. Muhamad et al., "Association between Health Risk Behavior and Suicidal Ideation, Continuous Sadness and Depression among Malaysian Youth," Glob. J. Health Sci., vol. 10, no. 1, p. 11, Nov. 2018.

[38] N. Ibrahim et al., "The role of social support and spiritual wellbeing in predicting suicidal ideation among marginalized adolescents in Malaysia," BMC Public Health, vol. 19, no. S4, p. 553, Jun. 2019.

[39] W. C. Chin and S. L. Wu, "The predicting effects of depression and self-esteem on suicidal ideation among adolescents in Kuala Lumpur, Malaysia," J. Heal. Transl. Med., vol. 23, no. 1, pp. 60-66, 2020.

[40] W. C. Chin and S. L. Wu, "The predicting effects of depression and self-esteem on suicidal ideation among adolescents in Kuala Lumpur, Malaysia," J. Heal. Transl. Med., vol. 23, no. 1, pp. 60-66, 2020. 